Dying and dead seas : climatic versus anthropic causes; [proceedings of the NATO

Advanced Research Workshop on Dying and Dead Seas - Climatic versus Anthropic

Causes, Liège, Belgium, 7 - 10 May 2003] / ed. by Jacques C. J. Nihoul ... (Eds.). -

Dordrecht [u.a.] : Kluwer Academic, 2004. - S. 253-286. - ISBN 1-402-01901-7

\title{
Chapter
}

\section{1,000-YEAR ENVIRONMENTAL HISTORY OF LAKE ISSYK-KUL}

\author{
Santiago Giralt and Ramon Julià \\ Institute of Earth Sciences "Jaume Almera" (CSIC), Lluís Solé i Sabarís, s/n, E-08028 \\ Barcelona, Spain (sgiralt@ija.csic.es) \\ Jean Klerkx
}

International Bureau for Environmental Studies (IBES) Rue Audrey Hepburn 9/13, B-1090 Bruxelles, Belgium

Santiago Riera

Department of Archaeology, Faculty of History, University of Barcelona, Baldiri i Reixach s/n, E-08028 Barcelona, Spain.

\section{Suzanne Leroy}

Department of Geography and Earth Sciences, Brunel University (West London), Uxbridge UB8 3PH, UK.

Teresa Buchaca and Jordi Catalan

Centre d'Estudis Avançats de Blanes (CEAB-CSIC), Accès a la cala Sant Francesc 14, E17300 Blanes, Spain.

Marc De Batist

Renard Centre of Marine Geology, Geological Institute, University of Gent, Krijgslaan 281 S.8, B-9000 Gent, Belgium.

\section{Christian Beck}

Laboratoire de Géodynamique des Chaines Alpines, U.M.R. C.N.R.S. 5025, Université de Savoie, Campus Savoie-Technolac, 73376 Le Bourget-du-Lac Cedex, France.

Vladimir Bobrov, Vselodov Gavshin, Ivan Kalugin and Feodorov Sukhorukov

United Institute of Geology, Geophysics and Mineralogy, Acad. Koptyug Prospekt, 3, RU- 
630090 Novosibirsk, Russia.

Matthias Brennwald, Rolf Kipfer and Frank Peeters

Swiss Federal Institute of Technology (ETH) and Swiss FederalInstitute of Environmental Science and Technology (EAWAG) CH-8600 Dübendorf, Switzerland.

Salvatore Lombardi

Department of Earth Sciences, University of Rome 'La Sapienza', P.le A. Moro, 5, Rome 00185, Italy

Vladimir Matychenkov and Vladimir Romanovsky

Institute of Water Problems and Hydropower. National Academy of Sciences of the Kyrgyz Republic, 720033 Bishkek, Republic of Kyrgyzstan

Victor Podsetchine

Pirkanmaa Regional Environment Centre, P.O.Box 297, FIN-33101 Tampere, Finland

Nunzia Voltattorni.

Istituto Nazionale di Geofisica e Vulcanologia Sezione Roma 1, Via di Vigna Murata 605, 00143 Roma, Italy.

\section{INTRODUCTION}

Lake Issyk-Kul constitutes one of the most important economic resources in the Republic of Kyrgyzstan, with more than 100 recreational centers along its shore. Some 370,000 holidaymakers visit the lake annually, and this number is expected to increase in the near future given the growing interest in natural environments (Romanovsky, 1990; Savvaitova and Petr, 1992). Thus, a fuller understanding of the past and present evolution of this ecosystem is essential for promoting and sustaining this natural habitat.

At present the lake is faced with two main hazards:

1. A decrease in the instrumental water level record by more than $3 \mathbf{m}$ since 1927 (Figure 1). Up to now, the precise reasons for the fall in the present water level remain unknown although a number of factors have been identified such as climate (a long-term decrease in regional moisture), tectonic activity (a deepening of the bottom of the lake) and anthropogenic 
activities (a progressive increase in water consumption for agricultural purposes) (Romanovsky, 2002).

2. The progressive pollution of the lake. This is attributed to the increase in the use of fertilizers given the expansion of agricultural activities on the shore of the lake (eutrophy of the water) and to the rise in the population occupying its shores. The later factor includes the input of non-treated waters from the surrounding villages to the lake as well as waste from the local industry (oil products, phenols and suspended particles). Particular cases of contamination include a cyanide spill in 1998 and the influx of particles into the lake from former uranium mining wastes on the southern shores since the 1950s.

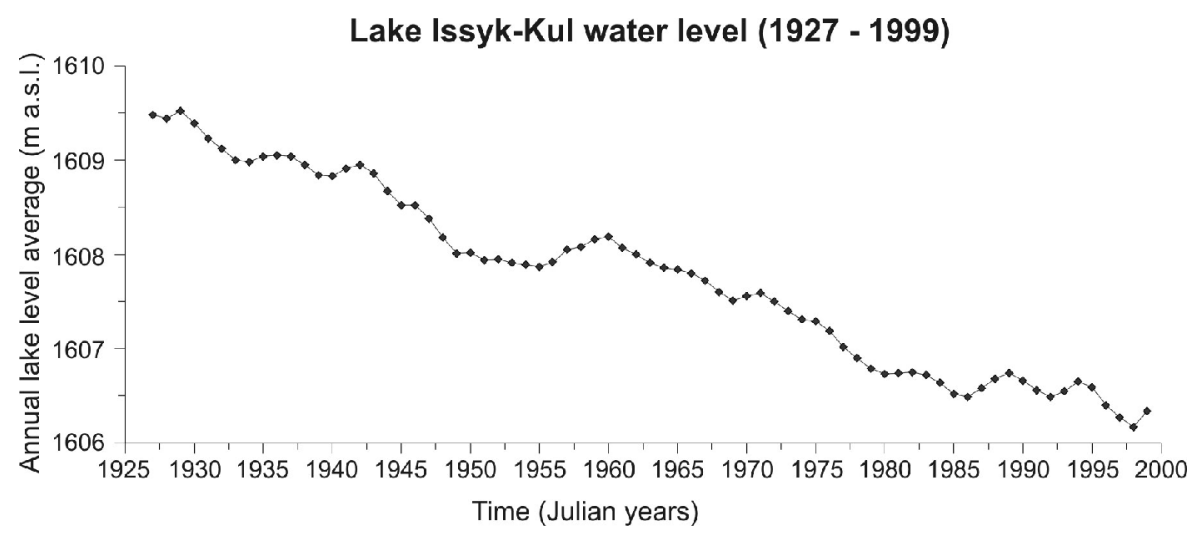

Figure 1. Instrumental water level oscillations of Lake Issyk-Kul for the period 1927 - 1999 (Modified from Romanovsky, 2002).

This has led to the drastic decline in fishing (from $1129 \mathrm{Tm}$ in 1965 to 160 $\mathrm{Tm}$ in 1985), the degradation of the water quality and the incorporation of toxic chemical compounds in the food web with deleterious consequences for the population of this area (Savvaitova and Petr, 1992).

In an attempt to determine the present-day environmental status a large multidisciplinary study was conducted. Thus, physical parameters of the water were measured, together with current measurements. An equation of state was established to develop a conceptual model for deep-water mixing (Hofer et al., 2002). Rates of deep-water exchange were estimated from measurements of transient tracers. One-dimensional box-model was developed to determine the long-term deep-water exchange and to quantify the mass fluxes of chemicals. A hydrodynamic model, which illustrated the transport and mixing today and in the near future, was built. Geochemical profiles in the water column were carried out to determine the geochemical cycle, to identify the places of input, and also to define the possible areas of contaminant concentration. The amount of radioactive contamination was evaluated (see the web page of the EU project APELIK 
http://www.uiggm.nsc.ru/issyk-kul for further details).

The recent environmental evolution of Lake Issyk-Kul was also studied to establish historical trends and past environmental changes. A thorough knowledge of the sedimentary processes and environments in the lake is esential for the selection of the most suitable coring sites. To this end, an extensive high-resolution seismic profiling as well as a coring campaign were carried out (De Batist et al., 2002). The main biogeochemical processes controlling the formation and precipitation of the different endogenic mineral phases (especially those related to the microbial biscuits of vaterite (Giralt et al., 2001)) were also characterized. Finally, the environmental evolution of Lake Issyk-Kul for the last 1,000 years was determined and is presented below.

\section{SITE DESCRIPTION}

Lake Issyk-Kul (180 km long and $50 \mathrm{~km}$ wide, at about 1,600 $\mathrm{m}$ a.s.l.,) is a large, closed, slightly saline (about $6 \mathrm{~g} / 1$ of TDS), tectonically active intramountainous lake, located between the Kungey (northern part) and Terskey (southern part) Ranges in the Tien Shan mountains (Republic of Kyrgyzstan, Central Asia). These ranges reach altitudes of 5,000-6,000 m a.s.l. (Figure 2). The catchment area of the lake is relatively small $(250 \mathrm{~km}$ long and $100 \mathrm{~km}$ wide) when compared with the size of the lake (Zabirov and Korotaev, 1978).

The lake is almond shaped. The littoral platforms, mainly located in the eastern and western sides of the lake, slightly dip up to water depths of 200 $\mathrm{m}$, transiting abruptly to a central deep, rectangular and flat shaped area $668 \mathrm{~m}$ deep (Figure 2). The littoral platforms of the northern and the southern shores are almost non-existent and they strongly dip up to this flat deep area. These steep slopes contain deep canyons which transfer the sedimentary particles from the shores to the flat deep area (De Batist et al., 2002).

The water chemistry of the lake is dominated by $\mathrm{Na}^{+}$and $\mathrm{K}^{+}$among the cations and by $\mathrm{Cl}^{-}$among the anions (Karmanchuk, 2002). The alkalinity ranges from $310 \mathrm{mg} / 1$ to $330 \mathrm{mg} / \mathrm{l}$ and the calcium content is about 115 $\mathrm{mg} / \mathrm{l}$. These slightly saline waters are oversaturated with respect to calcite, monohydrocalcite and vaterite, minerals found in the sediments (Giralt et al., 2001). The lake is monomictic and is considered to be oligotrophic to ultra-oligotrophic (2 - $3.8 \mu \mathrm{g} / \mathrm{l}$ of phosphorous) (Aladin and Plotnikov, 1993). The $\mathrm{pH}$ values range between 8.75 , at the surface of the lake, and nearly 8 at the bottom. The lake surface temperature in January is not less than $2-3^{\circ} \mathrm{C}$, and in July it reaches $19-20^{\circ} \mathrm{C}$. At depths of more than 100 $\mathrm{m}$, the water temperature remains constant all the year at $3.5-4.5^{\circ} \mathrm{C}$. High 
values of dissolved oxygen at the bottom of the lake $(6.5-7.5 \mathrm{mg} / \mathrm{l})$ demonstrates that the lake is well mixed (Hofer et al., 2002).

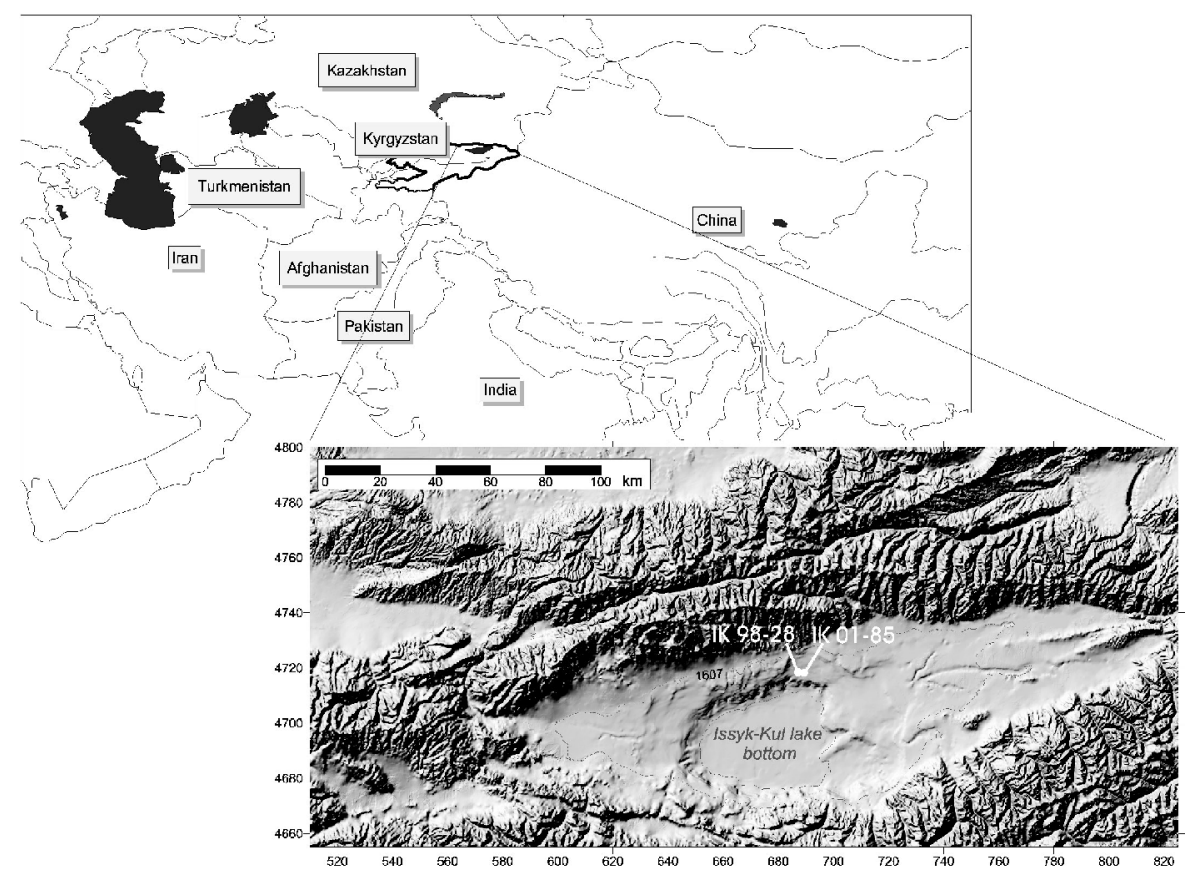

Figure 2. Geographical location of Lake Issyk-Kul (top). Digital Elevation Model (DEM) of Lake Issyk-Kul and its catchment area (Modified from Delvaux, 2001). Location of the cores IK 98-28 and IK 01-85.

The lake water circulation is cyclonic with strong horizontal water currents. Drift buoy measurements conducted during the expedition of March 2001 indicate the presence of water currents with horizontal velocities in the order of $0.5 \mathrm{~m} / \mathrm{s}$ down to at least $350 \mathrm{~m}$ depth. The deep-water renewal in Lake Issyk-Kul is rapid and the residence time of the deep water of the lake seems to be less than $10 \mathrm{yr}$ (Hofer et al., 2002). The mechanism driving the deep-water renewal seems to be the differential cooling. Differential cooling leads to dense cold water in the shallow eastern regions of the lake. This dense bottom water propagates along the channels towards the deep open-water region where it sinks as a density plume to a depth corresponding to the water density in the plume (Peeters et al., 2003).

The lake is fed by 102 streams and rivers, but the Jergueland and Tyup rivers are the main rivers contributing to it. All these streams and rivers are, in turn, fed by ice caps located in the surrounding mountains with an altitute exceeding 3,300 $\mathrm{m}$ a.s.l. This induces an annual lake level oscillation of about $20 \mathrm{~cm}$. The lake level rises from February to September because of thawing glaciers and falls from September to the following 
February owing to the accumulation of snow in the ice caps (Giralt et al., 2002).

In the Central Asia region airflow from the west predominates in the middle and upper troposphere and is one of the main sources of moisture (Aizen et al., 2001). The low pressure over Europe during the prevalence of Meridional Atmospheric Circulation Pattern favours the increasing frequency of synoptic processes associated with precipitation, e.g. influxes of air masses from west to east bringing moisture from the Mediterranean Sea (Aizen et al. 2001). Thus, the humid air masses are primarily carried by mid-latitude cyclonic air currents from the Atlantic Ocean through the Mediterranean Sea in spring and autumn although secondary cyclonic centers are also found over the Caspian Sea (Alpert et al., 1990; Cullen and DeMenocal, 2000). The climate in the lake catchment area is continental but highly variable (from warm, temperate, and dry in the western part to slightly moist in the eastern part). The annual precipitation averages 250 $\mathrm{mm}$ and the annual evaporation from the surface of the lake is approximately $700 \mathrm{~mm}$.

The vegetation around lake Issyk-Kul is arranged in altitudinal belts (Walter and Box, 1983; Issyk-Kol Biosphere, 2001; Chemonics International Inc., 2001; Giralt et al., 2002). The western part of the lake basin is surrounded by semi-desert vegetation that is characterized by Ephedra and Chenopodiaceae (Salsola, Suaeda). The dry steppe (Artemisia and Poaceae) is widespread at the bottom of the mountain slopes and along the shores of the eastern basin. These areas have been transformed by agricultural use. Hippophaё rhamnoides thickets grow along the river courses. The riparian ecosystem also contains Populus, Salix and Betula.

Only a very restricted deciduous belt of mostly fruit trees is present on the wetter west-facing slopes: Juglans, a series of Rosaceous fruit trees and pistachios. The tree belt in the south is dominated by Juniperus sp. and in the north by Picea shrenkiana. Abies sp. forests grow in the far north and west. The alpine and sub-alpine meadows and pastures (with sedges) are characterised by Poaceae and Lamiaceae amongst a rich diversity of other herbs.

The mountains are affected by considerable deforestation despite recent protection laws (Ministry of the National Environment Protection of the Kyrgyz Republic and UNEP/GRID Arendal, 2000). Excessive grazing has resulted in the loss of meadows. Wild and human-induced fires constitute a problem.

\section{MATERIALS AND METHODS}


Extensive seismic and coring campaigns were carried out to select the most suitable place for conducting the palaeoenvironmental reconstructions (see De Batist et al. (2002) for further details).

The palaeoenvironmental reconstruction was done using two sediment cores (IK-98-28 and IK-01-85) both located in the northern part of the lake (Figure 2) since this area apparently has not been disturbed by tectonic phenomena. Both cores were retrieved using a gravity corer. Core IK-98-28 was $1.80 \mathrm{~m}$ long whereas core IK-01-85 was $1.50 \mathrm{~m}$ long.

Both cores were split longitudinally, and one half was used for lithological description, digitalization with a CCD camera, and sampling. Core IK-9828 was subsampled for granulometry, x-ray diffraction, thin sections, charcoal, pollen and other palynological remains whereas core IK-01-85 was subsampled for $\mathrm{x}$-ray diffraction, pigments, spherical carbonaceous particles and charcoal remains.

The grain size analyses were conducted every 3 millimeters using a Malvern Instruments MasterSizer/E with a $2 \mathrm{~mW} \mathrm{He}-\mathrm{Ne}$ laser $(633 \mathrm{~nm}$ wavelength). X-ray diffractions were done with an automatic Brucker D $5005 \mathrm{x}$ - ray diffractometer: $\mathrm{Cu}$ radiation $(\mathrm{K} \alpha=1.5405), 40 \mathrm{kV}, 30 \mathrm{~mA}$ and graphite monochromator. The mineralogical composition of core IK-98-28 was obtained every $5 \mathrm{~cm}$ whereas analyses were performed every $1.5 \mathrm{~cm}$ for core IK-01-85.

The thin sections from sediment samples were obtained after freeze-drying and balsam hardening and 100 thin sections were studied. Thin sections were digitalized using a CCD camera, and images were for several measurements employing Scion Image software, following the technique of Francus (1998).

The uppermost $38 \mathrm{~cm}$ of the core IK-01-85 were inspected for charcoal remains and carbonaceous particles. The samples were treated according to Yang et al. (2001). They were digested with $\mathrm{HNO}_{3}$ at $80{ }^{\circ} \mathrm{C}$ for $2 \mathrm{~h}$ to remove the reactive organic material as well as the carbonate particles, and with $\mathrm{HF}$ also at $80{ }^{\circ} \mathrm{C}$ for $2 \mathrm{~h}$ to remove the siliciclastic minerals (Rose, 1994). Lycopodium tablets were added after the chemical treatment in order to quantify carbonaceous particle concentrations (Stockmarr, 1971). The quantification of particles was carried out under the light microscope. Electron microscope observations were carried out to characterize the different particle morphologies, and the attached microprobe to this microscope was used to determine their chemical composition.

Three main categories of carbonaceous particles were distinguished according to their morphologies: Spheroidal Carbonaceous Particles (SCP), unperforated-like spheres and semispheres and plant remains (ligneous and 
herbaceous) (Figure 5). In addition, plant particles were subdivided into two groups according to their size $(>50 \mu \mathrm{m}, 20-50 \mu \mathrm{m})$.

The frozen sediment samples were freeze-dried prior to pigment extraction. Pigments were extracted from c. $1 \mathrm{~g}$ freeze-dried sediment in $4 \mathrm{ml} 90 \%$ acetone with a probe sonicator $(50 \mathrm{~W}, 2 \mathrm{~min})$. The extract was filtered through Whatman ANODISC $0.1 \mu \mathrm{m}(\varnothing=25 \mathrm{~mm})$ and analyzed by HPLC. The HPLC system was equipped with a Waters 600E solvent delivery system, an autosampler Waters 717 set at $4{ }^{\circ} \mathrm{C}$, a C18 column (dimensions: 250 x $4.6 \mathrm{~mm}$, particle size: $5 \mu \mathrm{m}$, Spherisorb ODS1 Waters) and a Waters 996 photodiode array detector. The detector was set at 440 and $660 \mathrm{~nm}$ for carotenoid and phorbin peak integration, respectively. Analytical separation was achieved by linear gradient $(1.2 \mathrm{ml} / \mathrm{min}$, constant flow) using a modification of the system described by Wright et al. (1991). After sample injection (100 $\mu \mathrm{l}$ of extract), pigments were eluted by linear gradient from 100\% solvent A (51:36:13 methanol:acetonitrile:MilliQ water, $\mathrm{v} / \mathrm{v} / \mathrm{v} 0.3 \mathrm{M}$ ammonium acetate) to $75 \% \mathrm{~A}$ in $5 \mathrm{~min}$ followed by an isocratic hold for 5 min at $75 \%$ A and to $100 \%$ solvent B (70:30 ethyl acetate:acetonitrile, v/v) in $20 \mathrm{~min}$. The solvent composition was returned to initial conditions over a 5 min gradient, followed by 5 min of system equilibration before injection of the next sample.

Pigments were identified by checking them against a library of pigment spectra obtained from several extracts of pure cultures of algae from the Culture Collection of Algae and Protozoa (CCAP) of The Windermere Laboratory (UK). Chl-a and Chl-b standards were obtained from Sigma Chemical Co. Ltd. (UK). The extinction coefficients used for calculations were those compiled by Davies (1976), Rowan (1989) and Jeffrey et al. (1997).

Twenty-three $5 \mathrm{~mm}$-thick samples for palynological studies were taken from the uppermost $41 \mathrm{~cm}$ of core IK 98-28 every two centimeters. The c. 1 $\mathrm{ml}$ samples were treated with the following method: sodium pyrophosphate, $\mathrm{HCl}, \mathrm{HF}, \mathrm{HCl}$, and finally sieving on 250 and $10 \mu \mathrm{m}$ meshes. The slides were mounted in glycerol. An estimation of the concentration was obtained by the initial addition of Lycopodium tablets to a known volume of sediment.

The sum for percentages was usually larger than 400 terrestrial pollen grains. The same sum was used for spores, pollen from aquatic plants, colonies of the green algae Botryococcus, fungal spores and other microfossils. The concentration units are number of pollen and spores per $\mathrm{ml}$ of wet sediment. The diagrams (Figures 8 and 9) were plotted using the software psimpoll 4.10 .

Zonation of different proxies such as mineralogy, pigments and pollen was established by the CONISS program of TILIA package, using the Edwards 
\& Cavalli-Sforza chord distance method (Grimm, 1987). The same zonation was applied to the concentration diagram. The palynological indicators of human activity were derived from the categories proposed by Behre (1981) for Europe.

In the palynological sequences located in the limits between forest and steppic environments AP is an excellent indicator of climate change, which is usually attributed to variations in moisture and to the continentality degree (Yafeng, 1993). The forest in the Lake Issyk-Kul area is located in the northern face of the Tien Shan Range whereas the southern face and the plains are dominated by steppe and semi-desert vegetation. Some authors have proposed moisture and continentality index based on several pollen taxons in an attempt to determine climate fluctuations using pollen sequences. Some studies on the present-day pollen deposition have shown that Chenopodiaceae is related to desert conditions whereas Artemisia indicates steppe environments. Since the pollinization mechanism of both vegetal species is similar, the Artemisia/Chenopodiaceae index can be used as a moisture index (Rhodes et al., 1996; Giralt et al., 2002).

The relatively high salinity of the water of Lake Issyk-Kul favours the extension of Chenopodiaceae on the shores of the lake during low lake level stands. Hence, the fluctuations of this vegetal taxon are not only triggered by moisture oscillations. The Artemisia/Ephedra index was used as an indicator of the regional moisture variations given that Ephedra is a palynological taxon indicating arid conditions (Gasse and Van Campo, 1994).

The chronology of the Lake Issyk-Kul sequences was based on ${ }^{210} \mathrm{~Pb},{ }^{137} \mathrm{Cs}$ and on AMS ${ }^{14} \mathrm{C}$ data derived from Ricketts et al. (2001). ${ }^{210} \mathrm{~Pb}$ was measured in two cores (IK 98-28 and IK 01-85) whereas ${ }^{137} \mathrm{Cs}$ only was measured in IK 01-85 (Figure 9). IK 01-85 was subsampled in $5 \mathrm{~mm}$-thick slices between 0 and $6 \mathrm{~cm}$ depth and $10 \mathrm{~mm}$ thick from 6 to $9 \mathrm{~cm}$ depth. IK 98-28 subsampling was more spaced. A low background $\gamma$-spectrometer equipped with $\mathrm{NaI}(\mathrm{Tl})$ scintillation detectors was used.

\section{RESULTS}

\subsection{Lithology}

Both cores showed the same lithological units, although their relative thicknesses were not the same. From the bottom to the top of the cores two lithological units can be differentiated:

1. Unit 2: This unit ranges from the $15 \mathrm{~cm}$ depth of core IK 98-28 and from the $13 \mathrm{~cm}$ of core IK $01-85$ to the bottom of both cores. It is mainly 
composed of a light - dark color alternation of silty-clays. From $86 \mathrm{~cm}$ to $136 \mathrm{~cm}$ of core IK $98-28$ and from $107 \mathrm{~cm}$ to the bottom of core IK 01-85 the textural composition of this alternation is slightly coarser (Giralt et al., 2002). Two types of color alternation are present: 1.- a millimetric alternation ( $1-2 \mathrm{~mm}$ thick) of light and dark gray lamina with clear boundaries. 2.- a centimetric alternation ( $1-2 \mathrm{~cm}$ thick) of light and dark gray layers. The boundaries are sharp at the top of the dark lamina and transitional at the bottom.

2. Unit 1: This unit is found in the uppermost $15 \mathrm{~cm}$ depth of the core IK 98-28 and in the $13 \mathrm{~cm}$ depth of the core IK 01-85 and is formed by massive light brownish silty-clays.

\subsubsection{Microlithofacies}

According to the thin sections, three microfacies were defined (see Giralt et al. (2002) for further details).

Light centimetric lamina: The first microlithofacies is composed of massive micritic carbonate with some terrigenous grains floating in this matrix. These grains are mainly rounded and homogeneous in size (with a mean size of $5 \mu \mathrm{m}$ ) and are mainly composed of quartz, hornblende and some elongated phyllosilicates, such as biotite, mainly arranged parallel to the surface of sedimentation. The presence of fragments of gastropods and diatoms is also noticeable.

Dark centimetric lamina: The second microlithofacies is constituted by massive micritic carbonate with large fragments of plant remains, mostly partially pyritized and some of them with a framboidal texture, and charcoal, as well as, black masses, which could be interpreted as sulfideand/or manganese- rich accumulation. These accumulations are laterally discontinuous, and their borders are diffuse.

Peletoidal lamina: The third microlithofacies is mainly composed of light massive micritic carbonate, rich in fecal pellet aggregates, with terrigenous minerals floating in this matrix, and large quantities of ostracods (complete shelves and fragments) and diatoms. In this case, the elongated particles are arranged without any preferential orientation.

\subsubsection{Facies distribution}

Petrological and SEM observations suggest that the main part of the carbonates composing these sediments is endogenic. The facies of these cores seem to correspond to distal shelf sedimentation, affected by muddy contribution (evidenced by the terrigenous grains) related to the Jergueland and Tyup rivers, as well as to the aeolian input. These microlithofacies are 
arranged forming couples of light (first microlithofacies) and dark (second microlithofacies) lamina. Only in the coarser textural alternation of the two cores are the light lamina represented by the peletoidal microlithofacies.

The origin of the millimetric alternation seems to be associated with the annual water level oscillation due to the melting of the ice cap that occurs in spring and to the ice accumulation in autumn. On the other hand, the centimetric alternation of these microfacies seems to be related to early diagenetic redox mobilization of iron associated with sulfate reduction and organic matter decay (see Giralt et al. (2002) for further details).

\subsection{Mineralogy}

The mineralogical composition of the two uppermost meters of the Lake Issyk-Kul infill is formed by two main fractions: an endogenic one (calcite, magnesian calcite, monohydrocalcite and palygorskite) and a terrigenous one (quartz, illite, clinochlorite, microcline, albite and riebeckite) (Giralt et al., 2002). Monohydrocalcite is the most abundant mineralogical species in the endogenic fraction whereas illite is the most common within the terrigenous fraction (Figure 3).

From bottom to top, and on the basis of the carbonate species dominance, four zones were defined:

1. Zone D: this is only found at the base of core IK 98-28 and it ranges from $180 \mathrm{~cm}$ to $147 \mathrm{~cm}$ depth. This zone is dominated by magnesian calcite with percentages that range between 30 and $55 \%$ of the total weight. Illite exhibits the highest percentages.

2. Zone C: this zone is located in core IK $98-28$ from $147 \mathrm{~cm}$ to $97 \mathrm{~cm}$ depth and in core IK 01-85 from $147 \mathrm{~cm}$ to $121 \mathrm{~cm}$ depth. Calcite is the main carbonate in this zone and its percentages range from 30 to $70 \%$. In both cores, the terrigenous fraction displays the lowest percentages.

3. Zone B: this zone is located between $97 \mathrm{~cm}$ and $83 \mathrm{~cm}$ depth in core IK 98-28 and between $121 \mathrm{~cm}$ and $107 \mathrm{~cm}$ depth in core IK 01-85. The main carbonate in this zone is magnesian calcite with percentages that range between 50 and $70 \%$. 


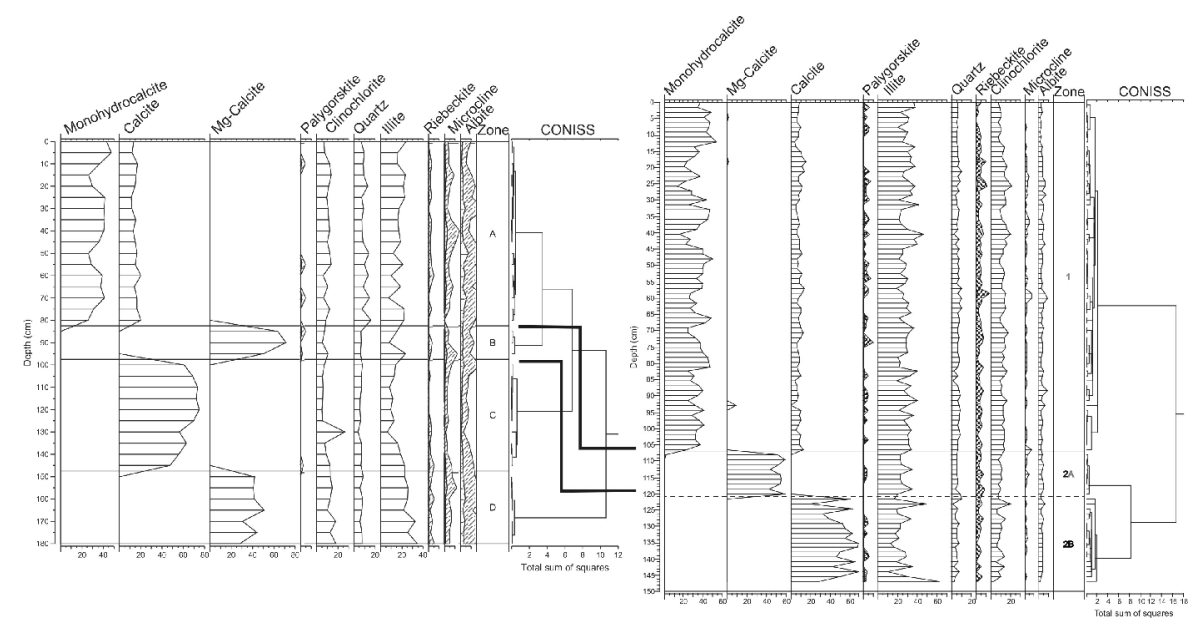

Figure 3. Mineralogical composition of core IK 98-28 (left) and of core IK 01-85 (right) and their mineralogical correlation.

4. Zone A: this zone corresponds to the upper $83 \mathrm{~cm}$ of core IK $98-28$ and to the upper $107 \mathrm{~cm}$ of core IK $01-85$ and is mainly composed of monohydrocalcite and of minor percentages of calcite. The percentages of the first carbonate range between 30 and $50 \%$ whereas those of the second carbonate are roughly constant (at about 15\%).

In spite of the different sampling resolution applied in the two cores (a sample every $5 \mathrm{~cm}$ in the case of core 98-28 and a sample every $1.5 \mathrm{~cm}$ in the case of core 01-85), their mineralogical content shows the same oscillations (Figure 4 left).

This correlation has allowed defining homologous points between both cores (Figure 4] left). The monohydrocalcite increases at $84 \mathrm{~cm}$ and at 47 $\mathrm{cm}$ in core IK 98-28 are located at $107 \mathrm{~cm}$ and at $65 \mathrm{~cm}$ in core IK 01-85. The differences in core depths between both cores were interpreted as different sedimentation rates. The depths of core IK 98-28 were adjusted to core IK 01-85 using the equation determined by the homologous points (Figure 4 right) given that nearly all the analyses were performed in this second core. This adjustment was performed in order to facilitate the comparison of the different proxies studied. 


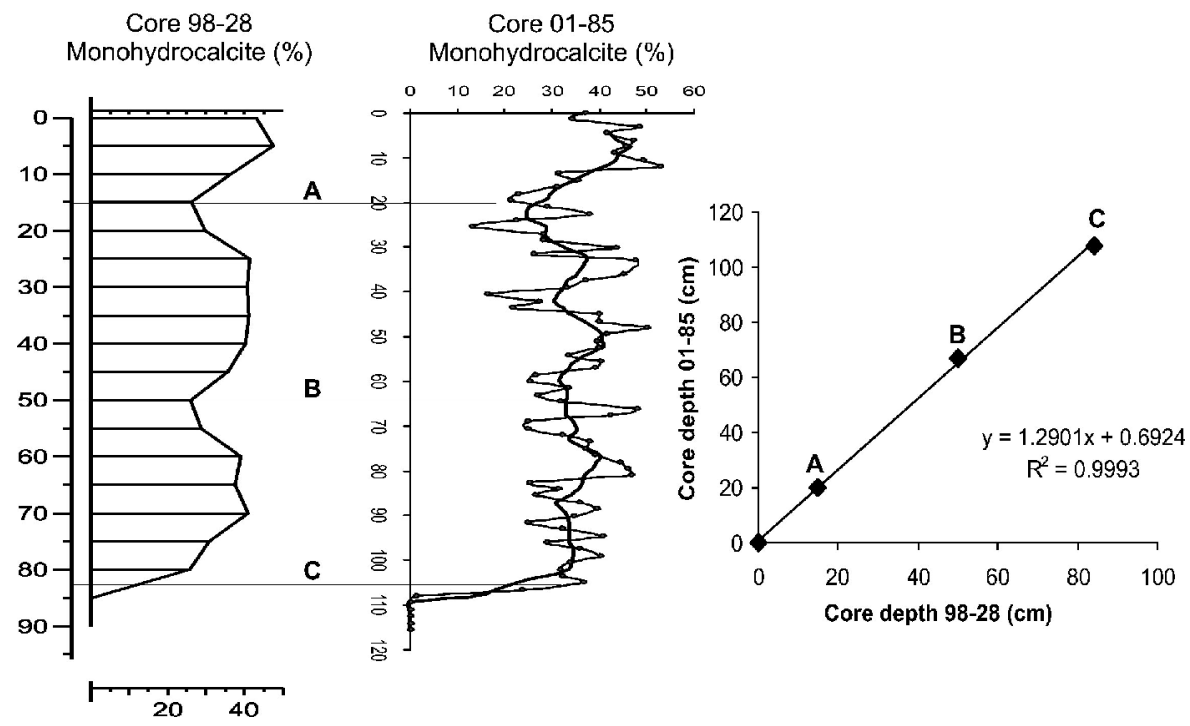

Figure 4. Correlation of the monohydrocalcite percentages of cores IK 98-28 and IK 01-85 (left). They show the same oscillations. Mathematical equation that relates the core depths of core 98-28 with those of core 01-85 (right).

\subsection{Carbonaceous particles}

According to the chemical composition, the sphere and the semisphere particles could be attributed to a combustion process, but their source is unclear. However, they do not preserve vegetal structures (Figure 5).

Total Carbonaceous Particles (TCP), spheres and semispheres as well as charcoal concentrations show similar patterns, suggesting that their origin and diffusion are related. The maximum carbonaceous particle concentration occurs between 22 and $15 \mathrm{~cm}$ depth, with a peak at $20 \mathrm{~cm}$. Secondary peaks occur at 32,17 and $11-14 \mathrm{~cm}$ depth (Figure 6).

Plant remains are more abundant than SCP, spheres and semispheres. Relative values of non-plant particles increase at $13-22,11$ and $2 \mathrm{~cm}$ depth. During the periods with low carbonaceous particle concentrations, plant remains are much more dominant (Figure 6).

Inside the group of plant particles, a progressive increase in burned herbaceous particles occurs, mainly after $24 \mathrm{~cm}$ depth coeval with the highest peak in carbonaceous particle concentration. Commonly, concentration of herbaceous particles is higher when total particle concentration is low. 


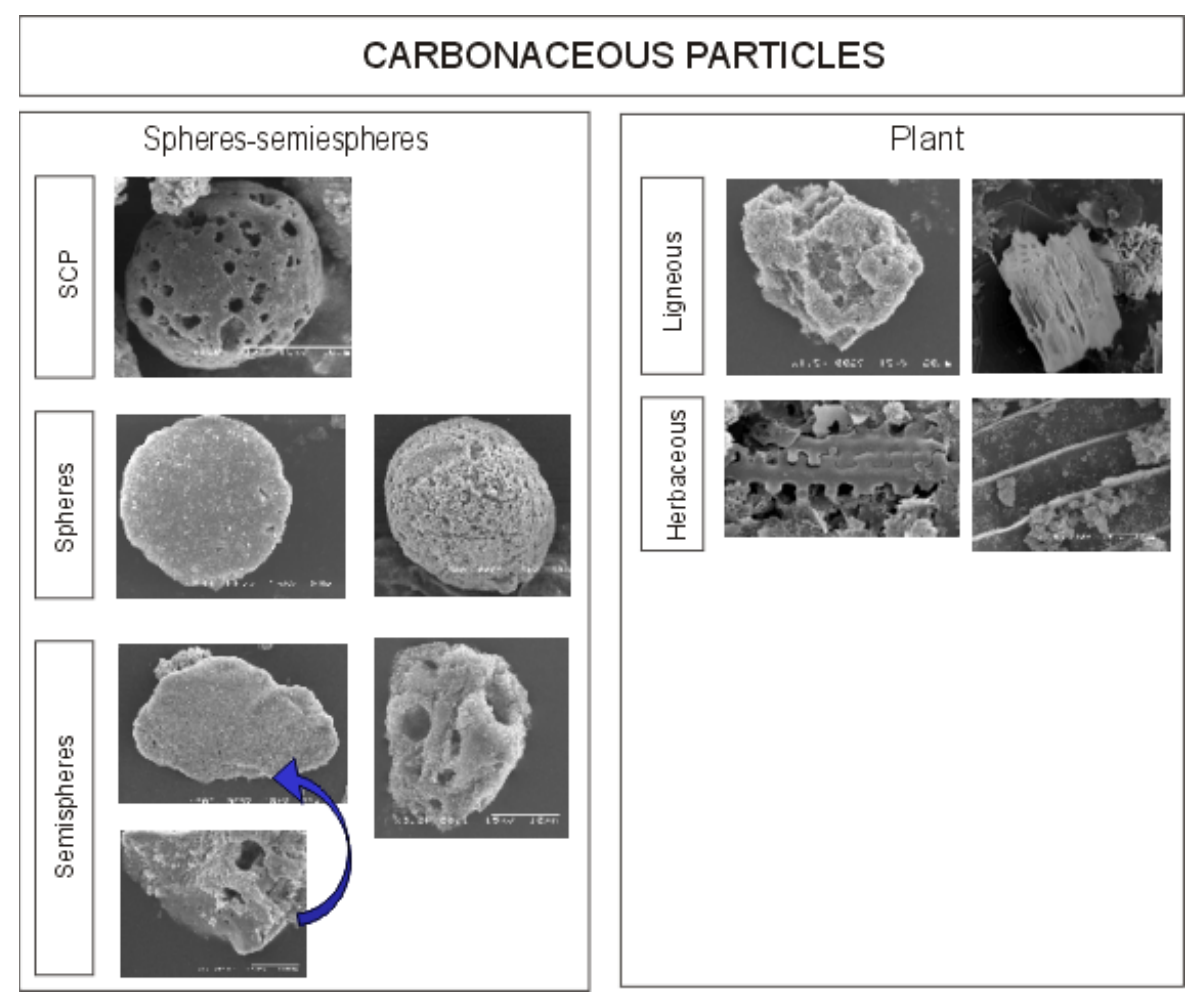

Figure 5. Different morphological combustion particles found in Lake Issyk-Kul sediments.

Plant particles ranging from 20 to $50 \mu \mathrm{m}$ are dominant along all the sequence with values higher than $80 \%$. Concentrations of plant particles larger than $50 \mu \mathrm{m}$ increase in the uppermost $22 \mathrm{~cm}$ (Figure 6).

\subsection{Pigments}

Pigment extracts contained a mixture of carotenoids and phorbins including some derivatives. Identified carotenoids were of two types, the carotenes and the xanthophylls. The carotenes were represented by $\beta \beta$-carotene, which was not detected in high amounts in the sediment record despite being present in all algal groups together with chlorophyll-a (Chl-a). On the other hand, the xanthophylls made up the majority of the carotenoids found and their diversity lead to their utility as taxonomic markers. Xanthophylls identified were marker pigments of Cryptophyta, Chlorophyta, Cyanobacteria and zooplanktonic invertebrates. Xanthophylls used as marker pigments of specific classes of algae are presented in Figure 7, which also shows their taxonomic affinities. 


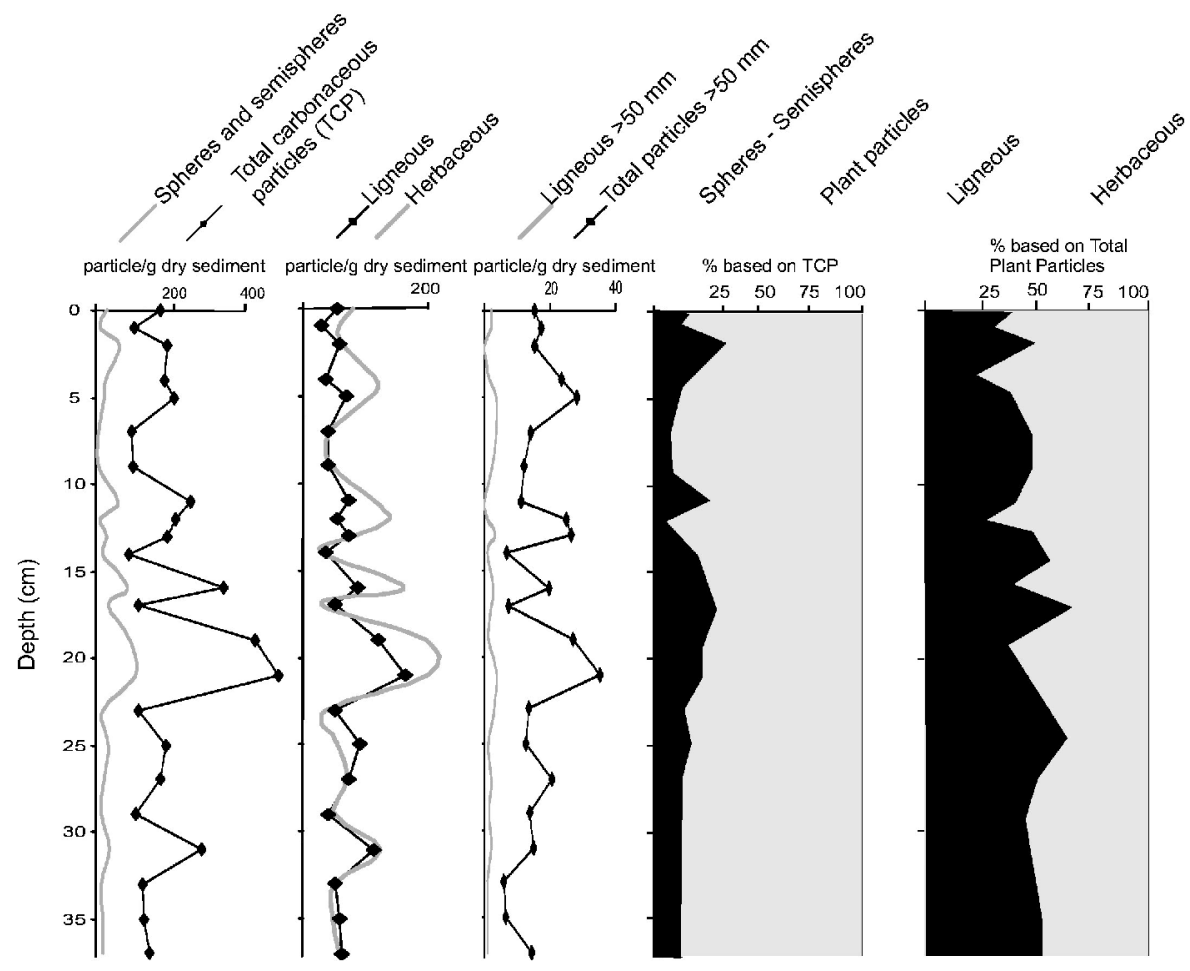

Figure 6. Different Spherical Carbonaceous Particles (SCP) and other plant remains of core 01-85. Number of particles expressed as total per gram of dry sediment (left) and expressed in percentages (right).

Phorbins were less important as marker pigments because most of them gave redundant information when xanthophylls were present. Identified aphorbins included Chl-a together with two of their derivatives, pheophytin$\mathrm{a}$ and Chl-a epimer. Pheophytin-b is a Chl-b derivative the only representative b-phorbin identified. Chl-a is the most ubiquitous pigment and it has traditionally been used as a general indicator of phytoplankton production whereas Chl-b is associated with Chlorophyta and higher plants. In addition, Bpheophytin-a, a derivative product of bacteriochlorophyll-a, was identified with no associated xanthophyll and was used as a marker pigment substitute for specific phototrophic bacteria.

Pigment concentration was in general very low along the record despite the fact that the samples integrated long time because of the high sediment compaction.

On the basis of pigment composition and from the bottom to the top of the sequence three zones were defined. The lowest pigment concentration was found in zone 3 (between 58 and $25 \mathrm{~cm}$ depth in Figure 7) and the highest in zone 2 (between 25 and $7 \mathrm{~cm}$ depth) with a maximum close to $15 \mathrm{~cm}$ 
depth. The sum of the Phorbins in Figure 7 behaves as a general phytoplankton production indicator since the main contributors to that sum in Lake Issyk-Kul sediments were a-phorbins. If we assume a constant sedimentation rate of terrigenous material along the sequence, the main productive period, evidenced by an increase in the Phorbin sum concentration, was situated in zone 2 .

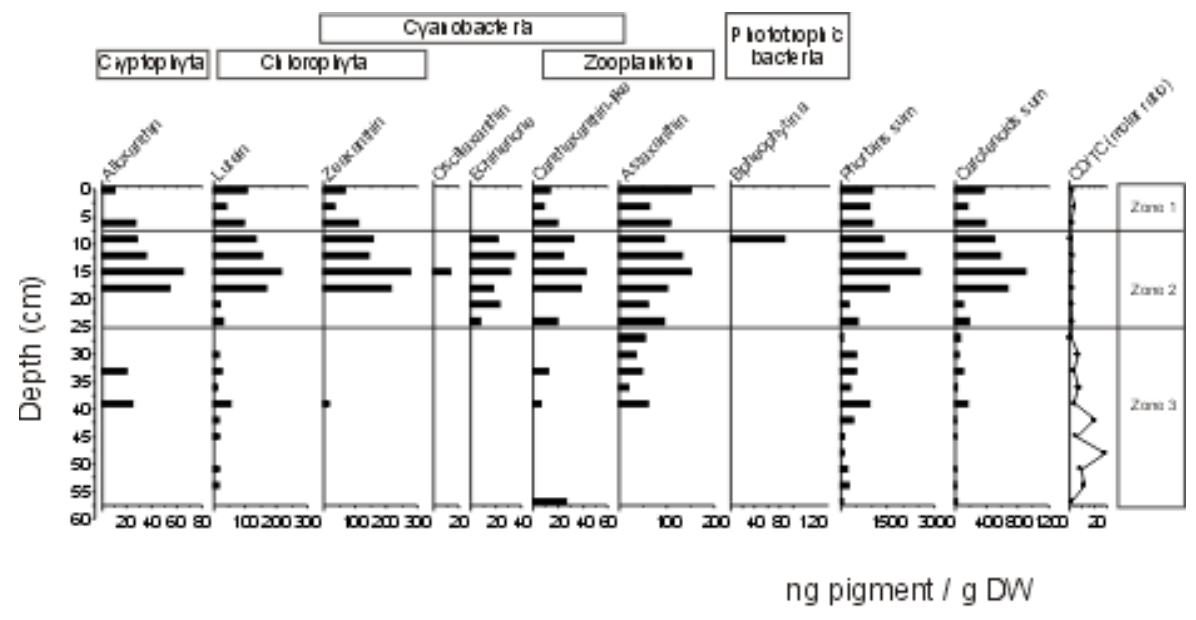

Figure 7. Pigment profile of core IK 01-85.

Echinenone, the main Cyanobacteria marker pigment identified, was present between 24 and $9 \mathrm{~cm}$ depth conciding with the main productive period. Situated at the maximum of this period appeared oscillaxanthin, which is a pigment highly specific to only two genera in the family Oscillatoriaceae (Cyanobacteria). The rise in Oscillaxanthin concentration has been used to date the onset of anthropogenic disturbances (Swain, 1985) and its presence suggests a change in the trophic status. The distribution of Cryptophyta and Chlorophyta marker pigments was wider, and extended above and below this layer. The zooplankton marker pigment astaxanthin appeared before the main productive period at the beginning of zone 2 whereas Bpheophytin-a was present in only one sample of the uppermost part after the main productive period. The presence of a phototrophic bacteria marker pigment suggests the existence of anoxic layers in the sediment surface.

Carotenoids degrade only slightly more rapidly than chlorophyll derivatives with the result that the ratio between total chlorophyll derivatives and total carotenoids (CD/TC) was used as an indicator of the amount originally deposited (Sanger, 1988). Since relatively more carotenoids than phorbins are produced in eutrophic lakes (Swain, 1985), the marked decrease in $\mathrm{CD} / \mathrm{TC}$ values above $40 \mathrm{~cm}$ depth can be attributed to a change in the overall algal community composition of the lake suggesting, a quick 
eutrophication of the water.

\subsection{Palynology}

The diagram is largely dominated by Non-Arboreal Pollen (NAP) (Figure 8 top, middle and bottom). Artemisia pollen percentages are mainly around $60 \%$.

Next in importance are Amaranthaceae-Chenopodiaceae (15 \%) and Poaceae $(8 \%)$. In general, a dry steppe belt (Artemisia and Poaceae) dominates the sequence, with strong influences from the nearby semidesert. The Abies forests do not seem to be recorded at all in the sedimentary sequence. It seems that pollen grains of Quercus are mostly the result of long-distance aerial transport, which is frequent in mountain settings especially with low biomass.

According to the cluster analysis and from the bottom to the top of the sequence six zones were defined:

\subsubsection{Palynological zone $6(63$ to $56 \mathrm{~cm})$}

This zone is characterized by maximum values of Asteraceae Liguliflorae (1-2 \%) and Cyperaceae (4-6 \%), and a minimum of Ephedra distachya type percentages. Poaceae $>37 \mu \mathrm{m}$ are present with $1.5 \%$ (Figure 9).

The large Poaceae pollen grains may have come from a variety of sources: wild or cultivated. Their small peak at $34 \mathrm{~cm}$ is not accompanied by other indicators of agriculture (such as Centaurea cyanus, Polygonum aviculare, Rumex acetosella, Fagopyrum and Brassicaceae, occasionally present in the

diagram), inviting caution as to the reconstruction of agricultural activities at this depth (Andersen, 1978).

\subsubsection{Palynological zone 5 (56 to $33 \mathrm{~cm})$}

This is a fairly stable zone in the percentage diagrams, whereas in the diagram of concentrations there is a maximum in the lower part $(63,114$ $\mathrm{g} / \mathrm{ml}$ ) followed by a decrease in the upper part. This is especially reflected by maximal concentrations of Artemisia, Amaranthaceae-Chenopodiaceae and Poaceae in the lower part of this pollen zone. Picea percentages are the lowest in this zone (2\%). This zone displays an increase in Ephedra distachya type, a bell-shaped curve of Caryophyllaceae at the center, and gently decreasing values of Cyperaceae. Amaranthaceae-Chenopodiaceae (19 \%) and Typha-Sparganium (1.2\%) have their maximum development in this zone. The values of Botryococcus show a progressive increase. 

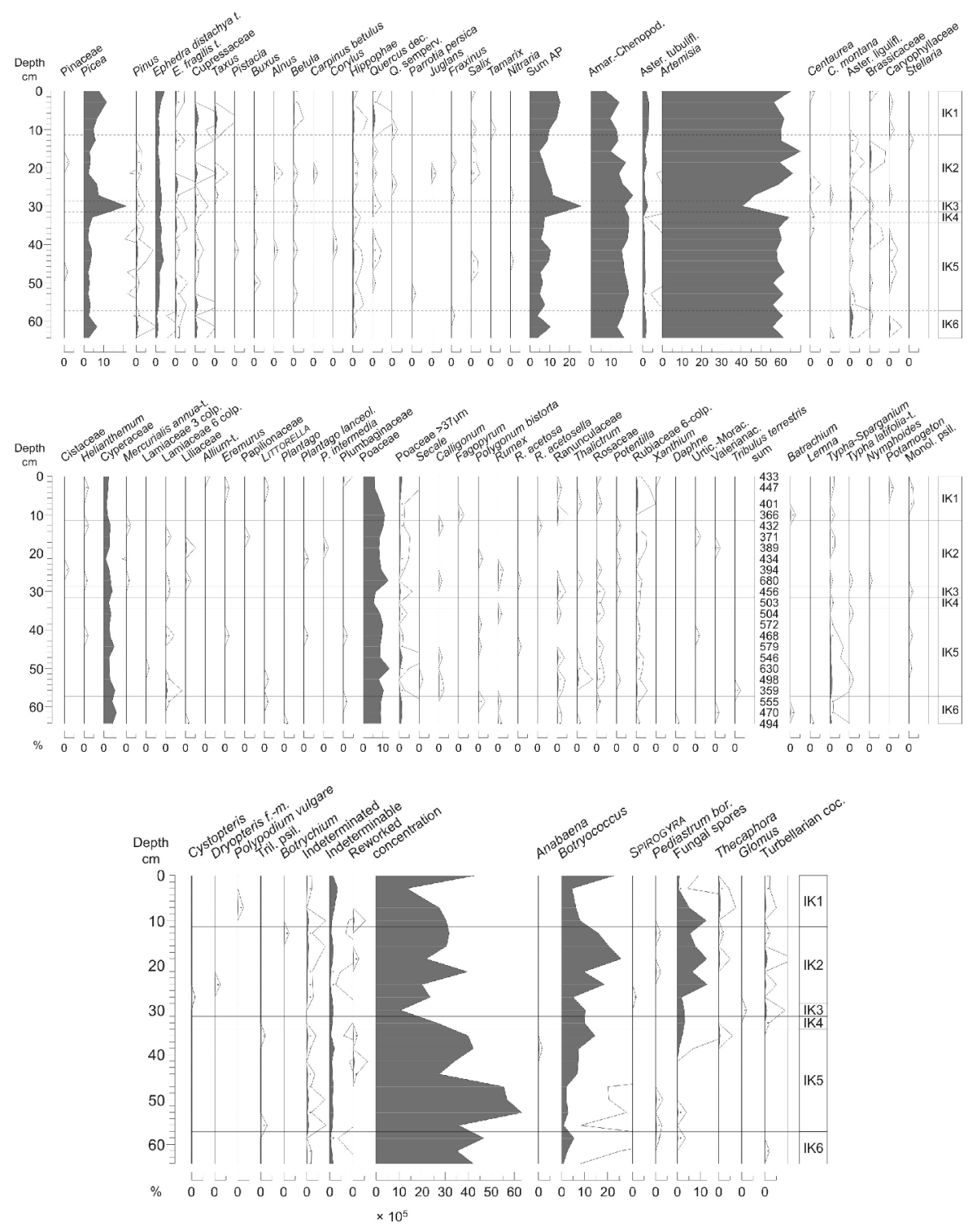

Figure 8. Arboreal and shrub pollen (AP) (top), Non Arboreal pollen diagrams (NAP) (middle) and other biological remains (bottom) from Lake Issyk-Kul. Curve exaggerated ten times. Black dot for values smaller than $0.05 \%$. "Sum AP" = sum of all arboreal pollen in percentages; "sum" number of terrestrial pollen grains counted; this sum is used to calculate all percentages. Concentration in grains per $\mathrm{ml}$ of wet sediment.

\subsubsection{Palynological zones 4 and 3 ( 33 to $28 \mathrm{~cm}$ )}

These two zones are discussed together given that they are made up of only 
one sample. They illustrate a brief period of rapid change. Zones 4 and 3 constitute the limit between the lower part of the diagram, rich in pollen, and the upper part, which is poorer. In addition, zone 3 is the poorest of the whole diagram $(10,531 \mathrm{~g} / \mathrm{ml})$. Zone 3 contains a brief maximum of Picea in the percentage diagrams, which scarcely appears in the concentration diagram (Figure 9). Artemisia drops by $23 \%$. The concentration diagram confirms this drop. This zone shows a continuous curve of fungal spores.

\subsubsection{Palynological zone $2(28$ to $12 \mathrm{~cm})$}

In this zone the percentage values of Picea start by decreasing and end by re-increasing. Pinus peters out towards the end of this zone. Amaranthaceae-Chenopodiaceae percentages progressively decrease whereas those of Artemisia reach their maximum. Rosaceae values do not return to previous percentages. The zone displays a maximal representation of fungal spores and Botryococcus.

Lake Issyk-Kul, core 98-28, in concentration Analysis: S. Leroy

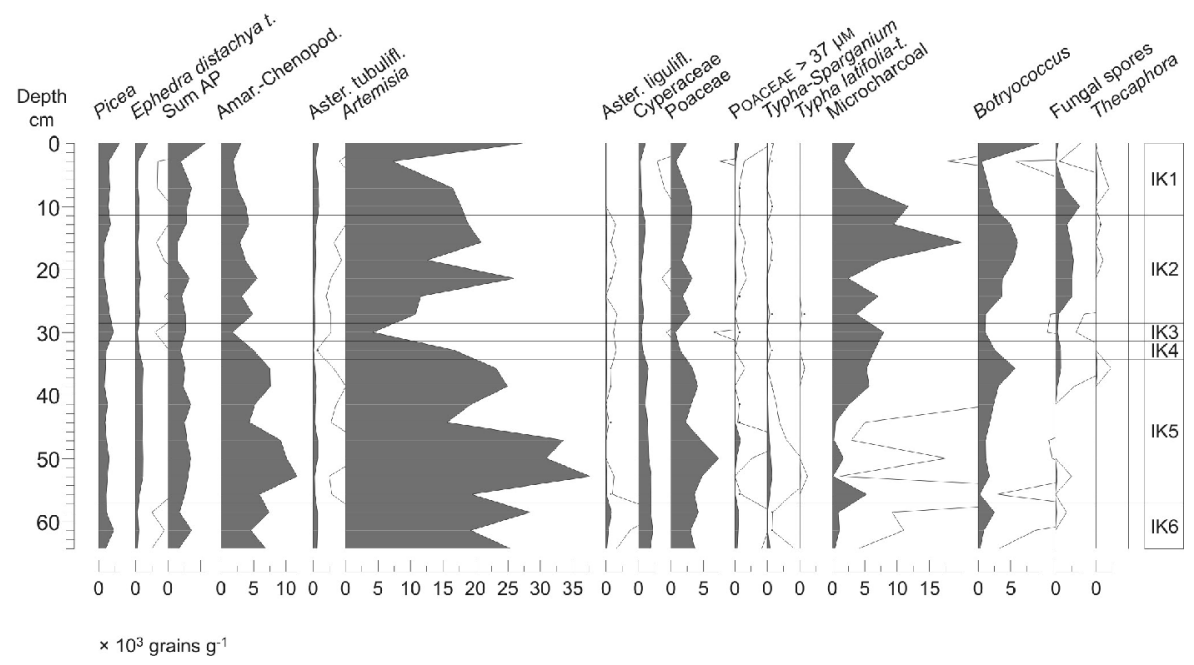

Figure 9. Concentration pollen diagram. Palynological diagram in concentration of selected taxa in grains per $\mathrm{ml}$ of wet sediment. Ten times exaggeration curve. Black dot for values smaller than 100 g.ml-1.

\subsubsection{Palynological zone 1 (12 cm to top)}

The Arboreal Pollen (AP) values increase in this zone owing to Picea and the two Ephedra taxa. The two Ephedra taxa reach their maximum percentages in the uppermost sample. The absence of Pinus pollen grains in this zone is striking. Cupressaceae (Juniperus most probably) percentages are relatively high $(1.7 \%)$ in the lower part of this zone but they disappear towards the top of the sequence. As regards Picea at $3 \mathrm{~cm}$ the percentage 
peak is visible but not the concentration peak. Maximum values are reached for Asteraceae Tubuliflorae percentages. Excluding the lowest sample of this pollen zone Rubiaceae (possibly Galium) have a continuous representation. In the concentration diagram, Artemisia values sharply increase in the uppermost sample. The percentages of AmaranthaceaeChenopodiaceae keep decreasing throughout this zone. The percentages of Botryococcus are now lower except for the uppermost sample. There is a steady decline of microcharcoals and fungal spores. This zone however shows a maximum of Thecaphora fungal spores.

\subsection{Chronology}

The ${ }^{210} \mathrm{~Pb}$ and ${ }^{137} \mathrm{Cs}$ concentration profiles of both cores are shown in Figure 10.

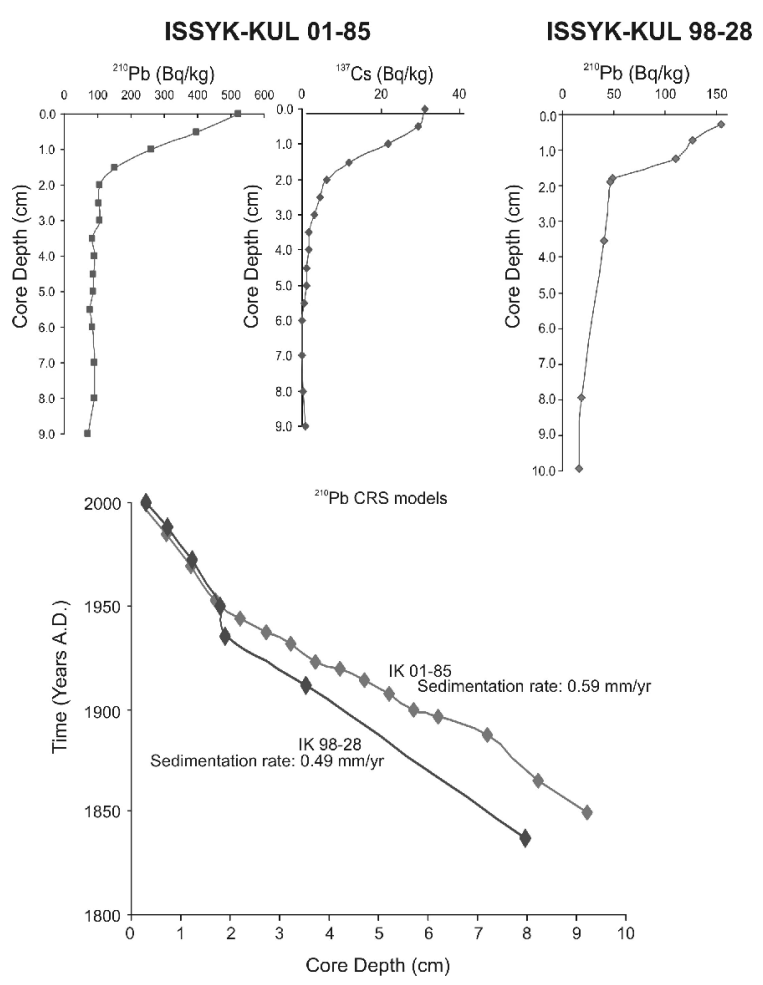

Figure $10 .{ }^{210} \mathrm{~Pb}$ and ${ }^{137} \mathrm{Cs}$ profiles of the cores $98-28$ (top left) and 01-85 (top right). CSR model calculated for both cores (bottom).

The highest value of ${ }^{210} \mathrm{~Pb}(155 \mathrm{~Bq} / \mathrm{kg}$ of dry sediment) for core IK $98-28$ is found in the uppermost-analyzed sample $(0.29 \mathrm{~cm})$. The ${ }^{210} \mathrm{~Pb}$ values abruptly decrease downcore to $50 \mathrm{~Bq} / \mathrm{kg}$ at $1.9 \mathrm{~cm}$ of core depth. From this depth down to $10 \mathrm{~cm}$ of core depth, the ${ }^{210} \mathrm{~Pb}$ values slightly decrease to 16 $\mathrm{Bq} / \mathrm{kg}$, this value being the lowest one. The same ${ }^{210} \mathrm{~Pb}$ pattern is observed 
for core IK 01-85. The highest ${ }^{210} \mathrm{~Pb}$ values are at the top of the core (523 $\mathrm{Bq} / \mathrm{kg}$ ) progressively decreasing downcore to $108 \mathrm{~Bq} / \mathrm{kg}$ at $2 \mathrm{~cm}$ of core depth. From this core depth to the lowest analyzed sample the ${ }^{210} \mathrm{~Pb}$ values slightly decrease almost to $72 \mathrm{~Bq} / \mathrm{kg}$. On the other hand, the ${ }^{137} \mathrm{Cs}$ profile of this core shows an increase in this artificial radionuclide between 3 and 2 $\mathrm{cm}$ depth. This increase was attributed to the 1950s on account of nuclear weapons testing (Cambray et al., 1989) .

\section{DISCUSSION}

\subsection{Chronology}

The lowest ${ }^{210} \mathrm{~Pb}$ activity values measured at $9 \mathrm{~cm}$ in core IK $98-28$ and at 8 $\mathrm{cm}$ in core IK $01-85$ were attributed to supported ${ }^{210} \mathrm{~Pb}$. The activities measured between 8 and $2 \mathrm{~cm}$ are quite similar, with minor oscillations. These oscillations could be ascribed to small changes in sedimentation rates. Owing to changes in sedimentation rates, a Constant Rate of Supply (CRS) model was used to establish a chronological model for the uppermost $10 \mathrm{~cm}$ (Appleby and Oldfield, 1978; Ugur et al., 2003) (Figure 10 bottom).

The results of the CRS models were the same for the uppermost $1.5 \mathrm{~cm}$ (1954) with a sedimentation rate of $0.32 \mathrm{~mm} / \mathrm{yr}$. Moreover, the results of core IK 01-85 resemble the ${ }^{137} \mathrm{Cs}$ increase in the 1950s. Between 2 and 10 $\mathrm{cm}$ depth, the sedimentation rate of core IK 01-85 was higher than in core IK $98-28$. Sedimentation rates were $0.59 \mathrm{~mm} / \mathrm{yr}$ for the first core and 0.49 $\mathrm{mm} / \mathrm{yr}$ for core IK 98-28.

These sedimentation rates agreed with those that were already available based on a set of 12 AMS ${ }^{14} \mathrm{C}$ dates (Ricketts et al., 2001). Sedimentation rates derived from these radiocarbon dates were $0.56 \mathrm{~mm} / \mathrm{yr}$ for core $11 \mathrm{P}$ and $0.47 \mathrm{~mm} / \mathrm{yr}$ for core $10 \mathrm{P}$ (Figure 11 ).

The age of the samples located above $10 \mathrm{~cm}$ of core depth were calculated using the CRS model for each sequence. Chronology was obtained for both cores below $10 \mathrm{~cm}$ depth, using the sedimentation rates obtained in each core. Similar ages were obtained by applying the previous calculated sedimentation rates $(0.59 \mathrm{~mm} / \mathrm{yr}$ for IK $01-85$ and $0.49 \mathrm{~mm} / \mathrm{yr}$ for core IK 98-28) to the samples located below $10 \mathrm{~cm}$ up to the level of appearance of monohydrocalcite. In core IK 98-28, the monohydrocalcite appeared at 84 cm depth corresponding to $289 \mathrm{AD}$ whereas in core IK 01-85 this mineral appeared at $107 \mathrm{~cm}$ depth corresponding to $189 \mathrm{AD}$. The difference in age of both cores (100 years) would only represent an error of $5 \%$. 


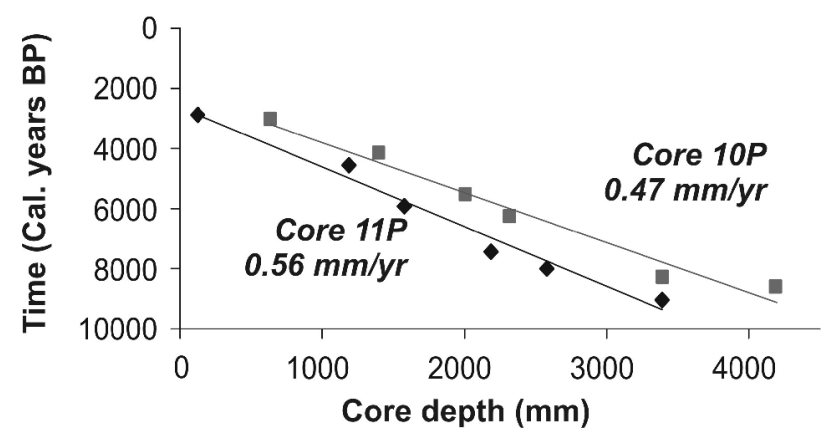

Figure 11. Sedimentation rates of two cores from Lake Issyk-Kul calculated using AMS ${ }^{14} \mathrm{C}$ dates (Modified from Ricketts et al., 2001).

\subsection{Origin of the sediment}

The sediments of cores IK 98-28 and IK 01-85 could have two main origins:

\subsubsection{Terrigenous fraction}

The terrigenous fraction is mainly composed of siliciclastic minerals (quartz, illite, albite, microcline, riebeckite and clinochlorite).

The mountain ranges of the Lake Issyk-Kul basin are mainly made up of crystalline basement rocks (granites and granodiorites) of Archaean to Middle Paleozoic age, covered by volcano-sedimentary strata of DevonianCarboniferous age (Atlas Kyrgyzskaja, 1987). The main source of terrigenous material entering in the lake is due to the erosion of these rocks by glacial and fluvial networks.

On the other hand, the grain size analysis and the electron microscope observations indicated that the mean grain size ranged between 6 and 10 $\mu \mathrm{m}$. These grain sizes have also been described as belonging to loess deposits (Ding et al., 2002). Moreover, the mineralogical composition of these loess deposits is dominated by siliciclastic particles (clays and feldspars). Recent works have shown that the Asian dust storm particles have a distinctive chemical signature with predominant calcium, silica and aluminum (Ma et al., 2001), indicating that they are siliciclastic minerals (Sun, 2002). This distinctive chemical signature has also been found in the Inilchek glacier located very close to Lake Issyk-Kul (Kreutz et al., 2001).

The Siberian and the Mongolian High-pressure cells over Central Asia are responsible for the remobilization of fine dust mainly from the Taklamakan 
desert, and for transporting it, through the westerlies over the Tien Shan to the Japan Sea (Sun, 2002). Historical Chinese records of dust rain, mainly generated by these dust storms, show that these storms were more frequent during cold and/or dry periods (Deer, 1984). Moreover, these dust storm periods coincided with the main eastern Asia nomadic migrations (Fang and Liu, 1992).

Thus, the terrigenous fraction is mainly composed of a fine mixture of aeolian and riverine sedimentary particles. The Jergueland and Tyup rivers are the main sediment contributors to Lake Issyk-Kul. Both cores are located in the distal part of deltaic deposits, and their sediments represent the fine-grained suspended load sediments from the water column, mainly controlled by the current regime, the thermal stratification characteristics of the water column and the suspended sediment load of the inflowing rivers (De Batist et al., 2002).

\subsubsection{Endogenic fraction}

The endogenic fraction is mainly composed of calcium carbonates (monohydrocalcite, calcite and magnesian calcite) and clays (palygorskite). Microbial biscuits of vaterite have been found only in the uppermost sediment of the shallow parts of the lake (Giralt et al., 2001).

The precipitation of monohydrocalcite and of vaterite has been usually associated with biological processes, especially with bacterial communities, among other factors (Rasmussen et al., 1996; Léveillé et al., 2000; Giralt et al., 2001). In fact, large communities of microbialites located at $100 \mathrm{~m}$ of water depth have been described in Lake Issyk-Kul and it has been proposed that they are the main promoters of the precipitation of monohydrocalcite (Rasmussen et al., 1996). A number of works have also demonstrated that the presence of phosphorous in the water (p.e. sodium hexametaphosphate or triphosphate) inhibits the spontaneous precipitation of anhydrous carbonates such as calcite even if these are oversaturated, and stabilizes the hydrated forms (Hull and Turnbull, 1973; Stoffers and Fischbeck, 1974; Clarkson et al., 1992). Whatever the exact mechanism triggering the monohydrocalcite precipitation, it seems evident that this mineral is an indicator of the productivity of the lake.

Over a longer timescale, the productivity of Lake Issyk-Kul seems to be controlled by the nutrient availability and by solar activity (solar irradiance, among other parameters). In fact, the nutrient input will also be related to the water availability (more rainfall, more vegetal cover and biomass but also more runoff, and thus, more nutrient input). Thus, the primary productivity of the lake (or in other words, the monohydrocalcite percentages) would be a direct function of the solar activity. 


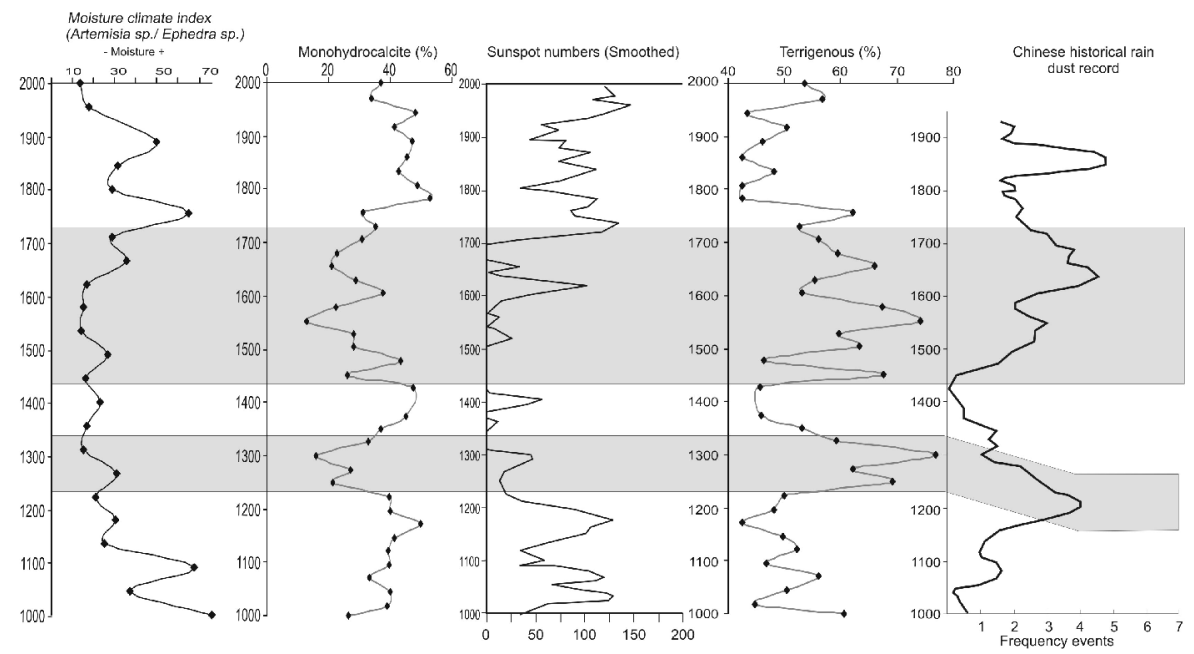

Figure 12. Comparison of the Moisture Climate index, the monohydrocalcite percentages, the reconstructed sunspot number (Modified from Rigozo et al., 2001), the terrigenous content and the reconstructed Chinese rain dust record (Modified from Deer, 1984).

The comparison of the monohydrocalcite percentages with the reconstructed sunspot numbers for the last millennium (Rigozo et al., 2001) shows a good agreement (Figure 12). In spite of the general low water availability and cold conditions during the period AD 1,200 - 1,710 and given the low number of sunspots, small fluctuations in the water availability (such as those that took place at about AD 1,400 and at about AD 1,700) led to a considerable increase in the lake productivity. Thus the long-term evolution of the water availability (high from at least AD 1,000 to 1,200 , low from 1,200 to 1,710 and high again from 1,170 to the presentday) is not recorded by the lake. On the other hand, this long-term evolution is evidenced by the vegetal cover. The moisture climate index (established using the Artemisia sp / Ephedra sp ratio) clearly shows these three water availability phases, but the short-term oscillations are less evident.

\subsection{Environmental periods}

According to the chronological model, the last 1,000 years are recorded in the upper $48 \mathrm{~cm}$ of the sedimentary infill of Lake Issyk-Kul. From the bottom to the top of the sequence, and on the basis of the oscillations of the analyzed proxydata 7 environmental periods were defined (Figure 13).

\subsubsection{Period VII (AD 1,000 - 1,180)}

During this environmental period, Lake Issyk-Kul was characterized by high water levels (high monohydrocalcite percentages) and by oligotrophic 
conditions (observed in the pigment index Chlorophyll derivatives / Total carotenoids) which increased upwards (progressive augmentation of the oligotrophy index). The regional environmental setting was characterized by a progressive decrease in the moisture (decrease in the pollen moisture climate index), provoking a slight fall in the arboreal biomass.

\subsubsection{Period VI (AD 1,180 - 1,308)}

From $\mathrm{AD} 1,180$ to 1,308 , the Lake Issyk-Kul water levels were reconstructed as progressively declining with its minimum at the beginning of the $14^{\text {th }}$ century. On the other hand it was during this period when the lake reached its maximum oligotrophic conditions (low monohydrocalcite percentages and highest values in the oligotrophy index). The regional moisture continued its progressive and fluctuating decrease. The beginning of the $14^{\text {th }}$ century recorded the driest conditions, as was suggested by a minimum in the moisture climate index. These driest conditions narrowed the spruce forest belt. The increase in the percentages of Typha-Sparganium suggest the formation of shallower areas in the lake and marshes related to a drop in the water level. The maximum expansion of marshy vegetation and hence the lower lake levels occurred in the first half of the $13^{\text {th }}$ century. Historical documents point out that the palace of Timur was constructed in these shallow areas at the end of the this century.

\subsubsection{Period V (AD 1,308 - 1,562)}

During this period of time the lake water level rose slightly (and the dilution of the pollen concentration indicates higher sedimentation rates), although the regional moisture continued to be low (as indicate by the moisture climate index), favouring a semi-desert vegetation similar to periods VII and VI. This rise in the water level led to an growth of primary productivity, mainly because of an increase in soil erosion (higher Botryococcus values) allowing nutrient input (with the subsequent decrease in the oligotrophy index). Towards the $16^{\text {th }}$ century the lake level diminished, reaching its minimum level at about 1,560 AD. Grazing activities near the lake shores commenced owing to the increase in fungal spores.

\subsubsection{Period IV (AD 1,562 - 1,681)}

From 1,560 AD there was a progressive increase in the regional moisture (steppe vegetation invades the semi-desert environment), which triggered a progressive rise in the water level (increase of monohydrocalcite percentages). On the other hand, this higher water availability favored soil erosion (evidenced by the high occurrence in fungal spores), and thus, the nutrient input to the lake, with a progressive growth of primary productivity of this lacustrine ecosystem (reduction of the pigment 
productivity index and enlargement of Botryococcus percentages). During this period anthropogenic pressure (grazing practices) was maximum. Deforestation due to wildfires reached its maximum values (highest carbonaceous particle

values), contributing to soil erosion and to fertilization of the lake.

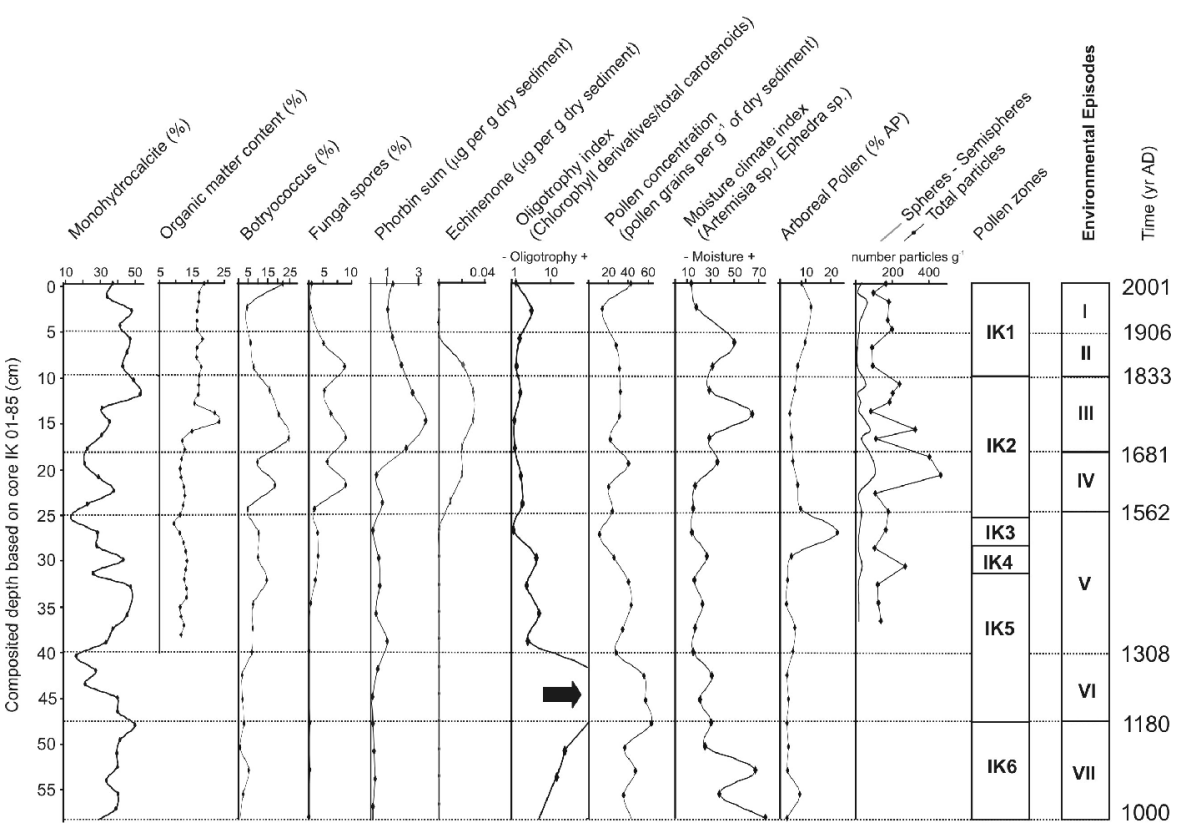

Figure 13. Environmental fluctuations occurred in Lake Issyk-Kul during the last 1,000 years.

\subsubsection{Period III (AD 1,681 - 1,833)}

In this period the lake reached its maximum primary productivity, which is reflected by the pigments but also by the total organic content. Moreover, the water level rose, reaching its highest level at the beginning of the $19^{\mathrm{h}}$ century, mainly because of the higher values of the regional moisture (maximum values of the moisture climate index and the increase of monohydrocalcite percentages). Historical data also demonstrate the existence of this lake level maximum (Romanovsky, 2002). The grazing activities were maximal. In fact, the incidence of wildfires seems to decrease favoring forest regeneration.

\subsubsection{Period II (AD 1,833 - 1,906)}

At the beginning of the $19^{\text {th }}$ century there was a slight decline in the anthropogenic pressure, mainly due to the decrease in grazing activities, which resulted in fewer wildfires. The improvement in the climate favored 
the expansion of forests. After the primary productivity and the water level maxima recorded in Period II there was a progressive decline in both parameters (decrease in the productivity index and in the Botryococcus percentages, respectively), indicating a reduction in the fertilization of the lake and soil erosion.

\subsubsection{Period I (AD 1,906 - 2,001)}

During the last 100 years, the water level and primary productivity continued their decline despite renewed activity in recent years. This fall in the water level, which has also been recorded in the instrumental water record, has been attributed to the expansion of the irrigated agricultural activities on the shores of the lake. Futhermore, a decrease in regional moisture has contributed to this. The reforestation by Scotch Pines, Iberian larches and walnut-trees (since 1948, Kyrgyz-Swiss Forestry Support program, 2003) does not seem to show in the palynological record.

\section{ACKNOWLEDGEMENTS}

We would like to thank George von Knorring for improving the final version of the manuscript. This work has received finantial support from the Inco-Copernicus program 'Assessment and prognosis of environmental changes in Lake Issyk-Kul (Kyrgyzstan) - APELIK' (Contract number : ICA2-CT-2000-10003).

\section{REFERENCES}

Aizen EM, Aizen VB, Melack JM, Nakamura T, Ohta T (2001) Precipitation and atmospheric circulation patterns at mid-latitudes of Asia. International J. Clim. 21: 535-556.

Aladin NV, Plotnikov IS (1993) Large saline lakes of former USSR: a summary review: Hydrobiologia 267: 1 - 12.

Alpert P, Neeman BU, Shay-El Y (1990) Climatological analysis of Mediterranean cyclones using ECMWF data. Tellus 42A: 65-77.

Andersen ST (1978) Identification of wild grass and cereal pollen. Damm. Geol. Unders. Arbog. 1978: 68-92.

Appleby PG, Oldfield F (1978) The calculation of $210 \mathrm{~Pb}$ dates assuming a constant rate of supply of unsupported $210 \mathrm{~Pb}$ to the sediment. Catena 5: 1 - 8 .

Atlas Kyrgyzskaja (1987) Moscow, 157 pp.

Behre KE (1981) The interpretation of anthropogenic indicators in pollen diagrams. Pollen et spores 23: $225-245$.

Cambray RS, Playford K, Lewis GNJ, Carpenter RC (1989) Radioactive fallout in air and rain: results to the end of 1987. Herwell, AERE-R, 13226. 
$\begin{array}{lccc}\text { Chemonics } & \text { International Inc. Biodiversity } \\ \text { Asian } & \text { Assessment for } & \text { Kyrgyzstan. USAID Central } \\ \text { Mission, } & \text { Almaty, } & \text { Kazakhstan } & \text { (2001) }\end{array}$ www.biofor.com/documents/Kyrgyzstan.pdf

Clarkson JR, Price TJ, Adams CJ (1992) Role of metastable phases in the spontaneous precipitation of calcium carbonate. J. Chem. Soc. Faraday Trans. 88: 243 - 249.

Cullen HM, DeMenocal PB (2000) North Atlantic influence on Tigris-Euphrates streamflow. Int. J. Clim. 20: 853-863.

De Batist M, Imbo Y, Vermeesch P, Klerkx J, Giralt S, Delvaux D, Lignier V, Beck C, Kalugin I, Abdrakhmatov KE (2002) Bathymetry and sedimentary environments of Lake Isssyk-Kul, Kyrgyz republic (Central Asia): a large, high-altitude, tectonic lake. In: J. Klerkx. and B. Imanackunov (Editors), Lake Issyk-Kul: its natural environment. NATO Science Series, Kluwer Academic Publishers, Netherlands, Earth and Environmental Sciences 13: $101-123$.

Davies BH (1976) Carotenoids. Academic Press, London, 36 pp.

Deer Z (1984) Synoptic-climatic studies of dust fall in China since historic times. Scientia Sinica (Series B) 27: 825 - 836 .

Delvaux D (2001) DTM of Issyk-Kul. Internal Report and CD-Rom. Unpublished.

Ding ZL, Ranov V, Yan SL, Finaev A, Han JM, Wang GA (2002) The loess record in southern Tajikistan and correlation with the Chinese loess. Earth and Planet. Sci. Let. 200: 387-400.

Francus P (1998) An image-analysis technique to measure grain-size variation in thin sections of soft clastic sediments. Sed. Geol. 121: 289-298.

Frang JQ, Liu G (1992) Relationship between climatic change and the nomadic southward migrations in eastern Asia during historical times. Clim. Change 22: 151 - 169.

Fritz SC (1996) Paleolimnological records of climatic change in North America. Limnol. and Oceanogr. 41: 882 - 889.

Gasse F, Van Campo E (1994) Abrupt post-glacial climate events in West Asia and North Africa monsoon domains, Earth and Planet. Sci. Let. 126: 435-456.

Giralt S, Julià R, Klerkx J (2001) Microbial biscuits of vaterite in Lake Issyk-Kul (Republic of Kyrgyzstan). J. Sed. Res. 71: 430 - 435.

Giralt S, Riera S, Klerkx J, Julià R, Lignier V, Beck C, De Batist M, Kalugin I (2002) Recent paleoenvironmental evolution of Lake Issyk-Kul. In: J. Klerkx. and B. Imanackunov (Editors) Lake Issyk-Kul: its natural environment. NATO Science Series, Kluwer Academic Publishers, Netherlands, Earth and Environmental Sciences 13: 125 - 145.

Grimm E (1987) A Fortran 77 Program for Stratigraphically Constrained Cluster Analysis by the Method of Incremental Sum of Squares. Computers \& Geosciences 13: 13-35.

Hofer M, Peeters F, Aeschbach-Hertig W, Brennwald M, Holocher J, Livingstone DM (2002) Rapid deep-water renewal in Lake Issyk-Kul (Kyrgyzstan) indicated by transient tracers. Limnol. and Oceanogr. 47: 1210 - 1216. 
Hull H, Turnbull AJ (1973) A thermodynamical study of monohydrocalcite. Geochim. Cosmochim. Acta 37: 163 - 170.

Issyk-Kol Biosphere (2001) www.issyk-kol-br.com.kg

Jeffrey SW, Mantoura RFC, Wright SW (1997) Phytoplankton pigments in oceanography: guidelines to modern methods, UNESCO Publishing, Paris, $661 \mathrm{pp}$.

Karmanchuk AS (2002) Water chemistry and ecology of Lake Issyk-Kul. In: J. Klerkx. and B. Imanackunov (Editors) Lake Issyk-Kul: its natural environment. NATO Science Series, Kluwer Academic Publishers, Netherlands, Earth and Environmental Sciences 13: 13 - 26.

Kreutz K, Aizen V, Cecil D, Wake C (2001) Dust deposition and isotopic composition of precipitation recorded in a shallow ice core, Inilchek glacier, central Tien Shan. J. Glaciol. 47: 549 - 554.

Kyrgyz-Swiss Forestry Support program (2003)

http://www.forest.kg/ForestrySector/for_type.htm

Léveillé RJ, Fyfe WS, Longstaffe FJ (2000) Geomicrobiology of carbonate - silicate microbialites from Hawaiian basaltic sea caves. Chem. Geol. 169: 339 - 355.

Ma CJ, Kasahara M, Höller R, Kamiya T (2001) Characteristics of single particles sampled in Japan during the Asian dust-storm period. Atm. Environ. 35: 2707-2714.

Ministry of the National Environment Protection of the Kyrgyz Republic and UNEP/GRID Arendal (2000) The State of the Environment of Kyrgyz Republic. http://www.grida.no/enrin/htmls/kyrghiz/soe2/index.htm

Peeters F, Finger D, Hofer M, Brennwald M, Livingstone DM, Kipfer R (2003) Deep-water renewal in Lake Issyk-Kul driven by differential cooling. Limnol. and Oceanogr. 48: 14191431.

Rasmussen KA, Romanovsky VV, MacIntyre IG (1996) Late Quaternary coastal microbialites and beachrocks of Lake Issyk-Kul, Kyrgyzstan: geologic, hydrographic, and climatic significance (abstract). Geological Society of America, Annual Meeting, Abstracts with Programs, 28: A-304.

Rhodes TE, Gasse F, Ruifern L, Fontes JC, Keqin W, Bertrand P, Gibert E, Mélières F, Tucholka P, Zhixiang W, Zhi-Yuan C (1996) Late Pleistocene Holocene lacustrine record from Lake Manas, Zunggar (northern Xinjiang, Western China). Palaeogeogr., Palaeoclim., Palaeoecol. 120: 105 - 121.

Ricketts R, Johnson TC, Brown ET, Rasmussen KA, Romanovsky VV (2001) The Holocene paleolimnology of Lake Issyk-Kul, Kyrgyzstan: trace element and stable isotope composition of ostracodes. Palaeogeogr., Palaeoclim., Palaeoecol. 176: 207 - 227.

Rigozo NR, Echer E, Vieira LEA, Nordemann DJR (2001) Reconstruction of Wolf sunspot numbers on the basis of spectral characteristics and estimates of associated radio flux and solar wind parameters for the last millennium. Solar Physics 203: 179 - 191.

Romanovsky VV (1990) Lake Issyk-Kul - a natural system. Ilim., Frunze (in Russian).

Romanovsky VV (2002) Water level variations and water balance of Lake Issyk-Kul. In: J. Klerkx. and B. Imanackunov (Editors). Lake Issyk-Kul: its natural environment. NATO Science Series, Kluwer Academic Publishers, Netherlands, Earth and Environmental 
Sciences 13: 45 - 58.

Rose NL (1994) A note on further refinements to a procedure for the extraction of carbonaceous fly-ash particles from sediments. J. Paleolim. 11: 201-204.

Rowan KS (1989) Photosynthetic Pigments of Algae. Cambridge Univ. Press, Cambridge, $334 \mathrm{pp}$.

Sanger JE (1988) Fossil pigments in paleoecology and paleolimnology. Palaeogeogr., Palaeoclim., Palaeoecol. 62: 343-359.

Sapozhnikov DG, Viselkina MA (1960) Recent sediments of the Lake Issyk-Kul and its bays, Moscow, Publishing House Akademii Nauk (in Russian).

Savvaitova K, Petr T (1992) Lake Issyk-Kul, Kirgizia. Int. J. Salt Lake Res. 1: 21 - 46.

Sevastyanov DV (1991) Historical-archaeological data on the changes of shores and lake level fluctuations. In The history of Sevan, Issyk-Kul, Balkhash, Zaisan and Aral lakes. Leningrad, Nauka.

Stockmarr J (1971) Tablets with spores used in absolute pollen analysis. Pollen et Spores 13: 615-621.

Stoffers P, Fischbeck R (1974) Monohydrocalcite in the sediments of Lake Kivu (East Africa). Sedimentology 21: 163 - 170.

Sun J (2002) Provenance of loess material and formation of loess deposits on the Chinese Loess Plateau. Earth and Planet. Sci. Let. 203: 845-859.

Swain EB (1985) Measurement and interpretation of sedimentary pigments. Freshwater Biology 15: 53-75.

Ugur A, Miquel JC, Fowler SW, Appleby P (2003) Radiometric dating of sediment cores from a hydrothermal vent zone off Milos Island in the Aegean Sea. The Sci. of the Total Environ. 307: 203214.

Walter H, Box EO (1983) The orobiomes of Middle Asia. In: N.E. West (Editor) Ecosystems of the world: temperate deserts and semi-deserts. Elsevier scientific publishing company, Amsterdam, 161 - 191.

Wright SW, Jeffrey SW, Mantoura RFC, Llewellyn CA, Bjornland T, Repeta D, Welschmeyer N (1991) Improved HPLC method for the analysis of chlorophylls and carotenoids from marine phytoplankton. Mar. Ecol. Prog. Ser. 77: 183-196.

Yafeng S, Zhaozheng K, Sumin W, Lingyu T, Fubao W, Tandong Y, Xitao Z, Peiyuan Z, Shaohua S (1993) Mid-Holocene climates and environments in China, Global and Planet. Change 7: 219-233.

Yang HR, Battarbee R (2001) Dating of recent catchment peats using spheroidal carbonaceous particle (SCP) concentration profile with particular reference to Lochnagar, Scotland. The Holocene 11: 593-597.

Zabirov RD, Korotaev VN (1978) Location and morphometry of the lake. Lake Issyk-Kul. Frunze, 12-20 (In Russian). 